\title{
Pemberian Dini Vasopresor pada Syok Sepsis
}

\author{
Ferianto $^{1 *}$, Ezra Oktaliansah ${ }^{2}$, Indriasari ${ }^{2}$
}

\begin{abstract}
Sepsis is life-threatening organ dysfunction caused by a dysregulated host response to infection and become one of leading causes of death in Intensive Care Unit (ICU). The two components of treating sepsis shock are fluid resuscitation and administration of vasopressor. Early administration of vasopressor in conjunction with fluid administration can reduce mortality because it reduces the volume of resuscitation so as to prevent excess fluid in the patient. Recent recommendation from Surviving Sepsis Campaign (SSC) suggest fluid resuscitation and medication within the first 1 hour including vasopressor administration in concomitant life-threatening cases of hyptension or immediately after fluid resuscitation to maintain MAP level $\geq 65 \mathrm{mmHg}$. Holistic treatment will reduce the mortality of patient with sepsis shock in the ICU.
\end{abstract}

Keywords: Sepsis, sepsis shock, ICU, vasopressor, Surviving Sepsis Campaign (SSC)

Sepsis adalah disfungsi organ yang mengancam jiwa akibat dari terjadinya disregulasi respon tubuh terhadap infeksi. Sepsis masih merupakan salah satu penyebab kematian utama di beberapa negara Eropa, disamping penyebab lain diantaranya infark miokard akut, stroke, dan trauma. Hampir $50 \%$ pasien yang di rawat di Intensive Care Unit (ICU) merupakan pasien sepsis. Salah satu penyebab utama tingginya mortalitas pasien sepsis adalah keterlambatan penanganan sehingga pasien jatuh dalam kondisi syok sepsis. Untuk mendapatkan hasil optimal, penanganan syok sepsis idealnya segera dilakukan pada 1 jam pertama. Syok sepsis merupakan bagian dari sepsis dimana terjadi abnormalitas sirkulasi dan metabolisme seluler yang dapat meningkatkan mortalitas. ${ }^{1}$

Dua komponen utama penanganan syok sepsis adalah resusitasi cairan dan terapi

Penulis untuk korespondensi: feri.131us@gmail.com

${ }^{1}$ Bagian Anestesi dan Perawatan Intensif RSUD

Dumai/Fellow Konsultan Intensive Care Fakultas

Kedokteran Universitas Padjajaran, Bandung, Jawa

Barat.

${ }^{2}$ Konsultan Intensive Care Fakultas Kedokteran

Universitas Padjadjaran, Bandung, Jawa Barat. vasopressor. Resusitasi cairan telah diterima secara luas sebagai terapi lini pertama, diikuti dengan pemberian vasopressor pada pasien dengan hipotensi persisten yang tidak respon dengan pemberian cairan sehingga perfusi jaringan tidak adekuat. Tetapi dengan perkembangan penelitian tatalaksana pasien sepsis di ICU pemberian dini vasopresor atau bersamaan dengan pemberian cairan memberikan hasil yang positif. Angka mortalitas pasien syok septik menurun dengan pemberian dini vasopresor. Hal ini berhubungan dengan berkurangnya volume cairan resusitasi sehingga mengurangi akumulasi cairan pada pasien. $^{2}$

Rekomendasi terbaru oleh Surviving Sepsis Campaign menyarankan resusitasi cairan dan terapi medikamentosa dalam 1 jam pertama, yang mencakup pemberian vasopresor sedini mungkin pada kasus hipotensi yang mengancam nyawa, bersamaan atau segera setelah resusitasi cairan untuk mempertahankan level MAP $\geq 65 \mathrm{mmHg}$. Penanganan yang holistik akan mengurangi mortalitas pasien syok sepsis di ICU. ${ }^{3}$

\section{Definisi}

Definisi sepsis mengalami perubahan dalam 
kurun waktu 1992-2016. Semula sepsis didefinisikan sebagai suatu sindroma respons inflamasi sistemik (SIRS) yang diakibatkan infeksi, namun pada tahun 2016 sepsis mengalami perubahan definisi menjadi suatu gangguan fungsi organ yang mengancam jiwa akibat dari terjadinya disregulasi respons tubuh terhadap infeksi. 1 Sedangkan syok sepsis didefinisikan sebagai sepsis yang disertai dengan gangguan sirkulasi, seluler, dan metabolik yang mengancam jiwa. ${ }^{1}$

Kelompok besar yang berkaitan dengan penelitian sepsis meliputi Protocolized Care for Early Septic Shock (ProCESS) di Amerika Serikat, Australasian Resuscitation in Sepsis Evaluation (ARISE) di Australia, dan Protocolised Management in Sepsis Trial (ProMise) di Inggris, melakukan evaluasi dan implementasi terhadap kasus sepsis. Dengan demikian, diperoleh pedoman baru, yaitu third international consensus definition for sepsis atau dikenal dengan sepsis-3. ${ }^{2}$

\section{Epidemiologi}

Pasien sepsis merupakan bagian terbesar dalam perawatan pasien di intensive care unit (ICU), hampir 50\% kasus. Angka kematian akibat sepsis di RSUP dr. Kandou Manado sebesar 65,7\%. Sedangkan angka perawatan sepsis di ICU RSUD dr. Soetomo sebesar $58,33 \%$ dengan $14,58 \%$ mengalami syok sepsis. ${ }^{3}$

Salah satu penyebab tingginya angka kematian sepsis adalah adanya keterlambatan penanganan awal, saat pasien ditangani di Instalasi Gawat Darurat (IGD). Faktor yang mungkin mengakibatkan keterlambatan penanganan diantaranya menunggu hasil laboratorium atau pemeriksaan penunjang lainnya. Untuk luaran yang optimal, penanganan awal pasien sepsis hendaknya segera dilakukan pada 1 jam pertama. ${ }^{4}$

\section{Etiologi}

Penyebab terbesar sepsis adalah bakteri Gram negatif (60-70\% kasus). Staphylococci, pneumococci, streptococci, dan bakteri Gram positif lain lebih jarang menimbulkan sepsis dengan angka kejadian antara $20-40 \%$ dari seluruh angka kejadian sepsis. Jamur oportunistik, virus, atau protozoa juga dilaporkan dapat menimbulkan sepsis dengan insidensi yang lebih jarang. Komponen lipopolisakarida (LPS) atau endotoksin glikoprotein yang merupakan komponen utama dari membran terluar bakteri gram negatif berpengaruh terhadap stimulasi pengeluaran mediator proinflamasi, yang kemudian akan menyebabkan terjadi inflamasi sistemik dan jaringan. Peptidoglikan merupakan komponen dinding sel kuman dilaporkan juga dapat menstimulasi pelepasan sitokin, yang juga berperan penting dalam proses agregasi trombosit.$^{5}$

\section{Patofisiologi Sepsis}

Respons inflamasi dan prokoagulan terhadap infeksi berkaitan sangat erat. Beberapa agen infeksi dan sitokin inflamasi seperti tumor necrosis factor $\alpha(\mathrm{TNF}-\alpha)$ dan interleukin-1 mengaktifkan sistem koagulasi dengan cara menstimulasi pelepasan tissue factor dari monosit dan endothelium yang memicu pembentukan trombin dan bekuan fibrin. Sitokin inflamasi dan trombin dapat mengganggu potensi fibrinolitik endogen dengan merangsang pelepasan inhibitor plasminogen-activator 1 (PAI-1) dari platelet dan endothelium. PAI-1 merupakan penghambat kuat aktivator plasminogen jaringan, jalur endogen untuk melisiskan bekuan fibrin. ${ }^{6}$

Efek lain dari trombin prokoagulan mampu merangsang jalur inflamasi multipel dan lebih menekan sistem fibrinolitik endogen dengan mengaktifkan thrombin-activated fibrinolisis inhibitor (TAFI). ${ }^{6}$

Mekanisme kedua melalui aktivasi protein aktif $\mathrm{C}$ yang berkaitan dengan respons sistemik terhadap infeksi. Protein $\mathrm{C}$ adalah protein endogen yang menginduksi fibrinolisis dan menghambat trombosis dan peradangan, merupakan modulator penting koagulasi dan peradangan yang terkait dengan sepsis. Kondisi tersebut memberikan efek antitrombotik dengan meng-inaktivasi faktor $\mathrm{Va}$ dan VIIIa, membatasi pembentukan trombin. Penurunan trombin akan berdampak terhadap proses inflamasi, prokoagulan, dan antifibrinolitik. Menurut data in vitro menunjukkan bahwa protein aktif $\mathrm{C}$ memberikan efek antiinflamasi dengan menghambat produksi sitokin inflamasi (TNF- $\alpha$, interleukin-1, dan interleukin-6) oleh monosit dan membatasi monosit dan neutrofil pada 
endothelium yang cedera dengan mengikat selectin. ${ }^{6}$ Hasil akhir respons jaringan terhadap infeksi berupa jejas endovaskuler difus, trombosis mikrovaskuler, iskemia organ, disfungsi multiorgan, dan kematian (Gambar 1). ${ }^{6}$

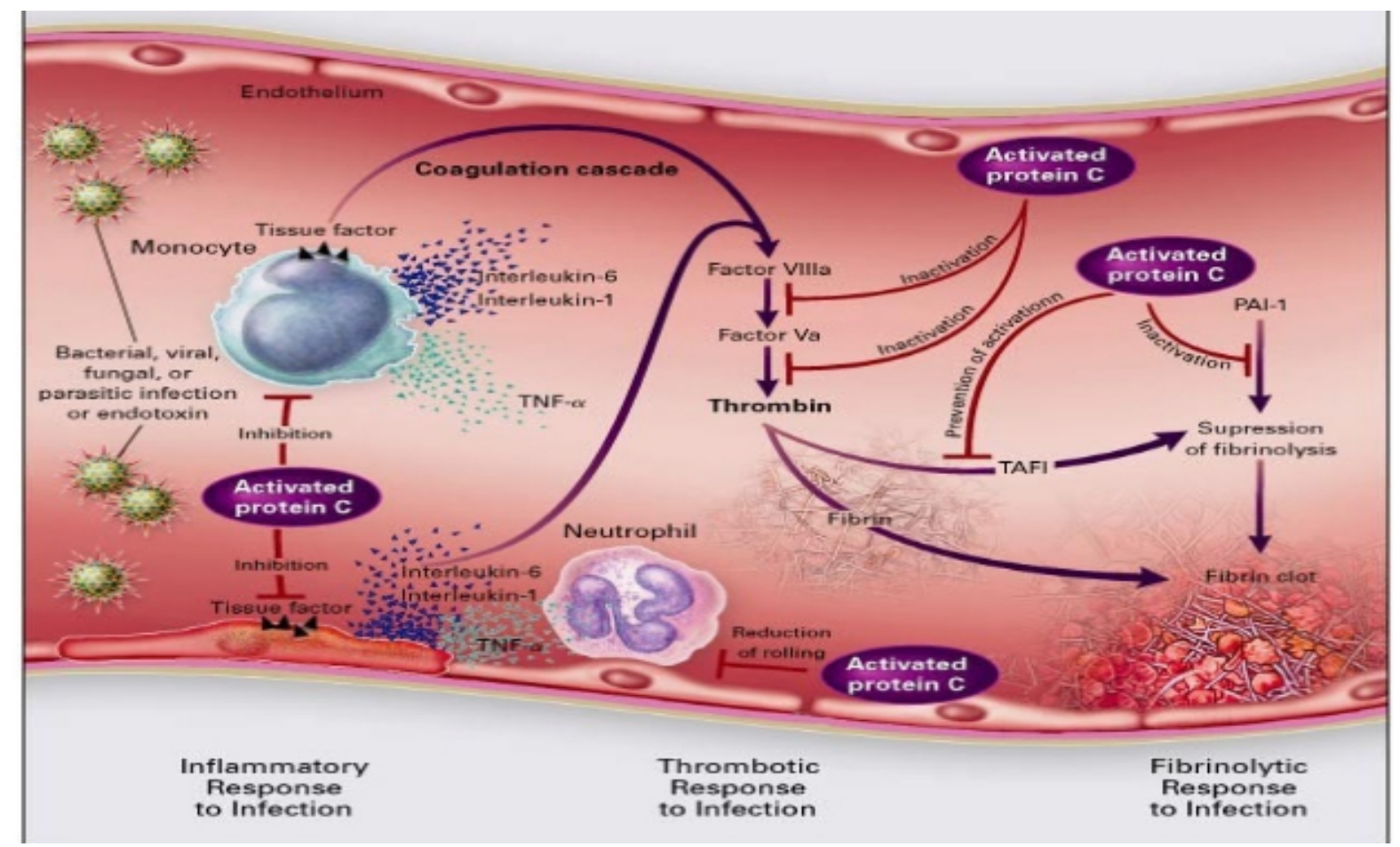

Gambar 1. Rantai koagulasi dengan dimulainya respon inflamasi, thrombosis, dan fibrinolisis terhadap infeksi

\section{Diagnosis Sepsis}

Identifikasi awal secara tepat merupakan hal yang krusial. Skrining awal dan cepat dapat dilakukan di setiap unit gawat darurat. Kriteria sepsis mengalami sejumlah perubahan seiring dengan berjalannya waktu. ${ }^{7}$

Kriteria baru sepsis menggunakan Sequential Organ Failure Assessment (SOFA).7 SOFA melakukan evaluasi terhadap fungsi fisiologis, respirasi, koagulasi, hepatik, sistem saraf pusat, dan ginjal. Makin tinggi skor SOFA akan meningkatkan morbiditas dan mortalitas sepsis (tabel 2). ${ }^{7}$ Kriteria SOFA muncul setelah pembaharuan definisi dan kriteria sepsis bertujuan untuk mengurangi morbiditas dan mortalitas sepsis. Kriteria tahun 1992 menggunakan istilah Sindrom Respons Inflamasi Sistemik (SIRS). SIRS terdiri dari kriteria umum yang meliputi kondisi vital pasien, terdapat kriteria inflamasi, kriteria hemodinamik, dan kriteria gangguan fungsi organ. ${ }^{7}$

\begin{tabular}{|ll|}
\hline & Tabel 1. Kriteria sepsis \\
\hline Kriteria SIRS & Suhu $:<36^{\circ} \mathrm{C}$ atau $>38^{\circ} \mathrm{C}$ \\
& Nadi $: 90$ kali $/$ menit \\
& Laju napas : $>20 /$ menit atau PaCO2 $<32 \mathrm{n}$ \\
& Leukosit $<4000 / \mathrm{mm} 3$ atau $>12000 / \mathrm{mm} 3$ \\
\hline Kriteria & Tekanan darah sistolik $<90 \mathrm{mmHg}$ \\
Hemodinamik & Tekanan arteri rerata $<70 \mathrm{mmHg}$ atau teka \\
& Saturasi darah vena $<70 \%$ \\
& Indeks kardiak $>3,5 \mathrm{~L} / \mathrm{menit} / \mathrm{m}$ \\
\hline Kriteria & Jumlah leukosit $>12000 / \mathrm{mm} 3$ atau $<4$ \\
Inflamasi & muda $>10 \%$ \\
& Kadar protein $\mathrm{C}$ reaktif meningkat $>2$ kali \\
& Kadar procalcitonin meningkat $>2$ kali nil \\
\hline Kriteria & PaO2/FIO2 $<300 \mathrm{mmHg}$ \\
Gangguan & Produksi urin $<0,5 \mathrm{mg} / \mathrm{kgBB}$ \\
Fungsi Organ & Gangguan pembekuan darah \\
& Ileus \\
& Trombositopenia \\
& Ikterus \\
\hline Kriteria & Kadar laktat $>3 \mathrm{mmol} / \mathrm{L}$ \\
Perfusi & Pengisian kapiler melambat \\
Jaringan & \\
\hline
\end{tabular}


JIK, Jilid 14, Nomor 2, September 2020, Hal. 69-80

Tabel 2. Sequential organ failure assessment (SOFA)

\begin{tabular}{|c|c|c|c|c|c|}
\hline \multirow[b]{2}{*}{ System } & \multicolumn{5}{|c|}{ Score } \\
\hline & 0 & 1 & 2 & 3 & 4 \\
\hline \multicolumn{6}{|l|}{ Respiration } \\
\hline $\mathrm{PaO}_{2} / \mathrm{Fio}_{2}, \mathrm{~mm} \mathrm{Hg}$ & $\geq 400$ & $<400$ & $<300$ & $\begin{array}{c}<200 \text { (with respiratory } \\
\text { support }\end{array}$ & $\begin{array}{c}<100 \text { with respiratory } \\
\text { support }\end{array}$ \\
\hline \multicolumn{6}{|l|}{ Coagulation } \\
\hline $\mathrm{Plt}, \times 10^{3} / \mathrm{mm}^{3}$ & $\geq 150$ & $<150$ & $<100$ & $<50$ & $<20$ \\
\hline \multicolumn{6}{|l|}{ Liver } \\
\hline Bilirubin, mg/dL & $<1.2$ & $1.2-1.9$ & $2.0-5.9$ & $6.0-11.9$ & $\geq 12.0$ \\
\hline \multicolumn{6}{|l|}{ Cardiovascular } \\
\hline $\mathrm{MAP} \geq 70 \mathrm{~mm} \mathrm{Hg}$ & $\begin{array}{c}\mathrm{MAP}<70 \\
\mathrm{~mm} \mathrm{Hg}\end{array}$ & $\begin{array}{c}\text { Dopamine } \\
<5 \mathrm{mcg} / \\
\mathrm{kg} / \mathrm{min} \text { or } \\
\text { dobutamine }\end{array}$ & (any dose) & $\begin{array}{c}\text { Dopamine } 5.1-15 \mathrm{mcg} / \\
\mathrm{kg} / \mathrm{min} \text { or epinephrine } \\
\leq 0.1 \mathrm{mcg} / \mathrm{min} \text { or } \\
\text { norepinephrine } \\
\leq 0.1 \mathrm{mcg} / \mathrm{kg} / \mathrm{min}\end{array}$ & $\begin{array}{l}\text { Dopamine }>15 \mathrm{mcg} / \\
\mathrm{kg} / \mathrm{min} \text { or epinephrine } \\
>0.1 \mathrm{mcg} / \mathrm{min} \text { or } \\
\text { norepinephrine } \\
>0.1 \mathrm{mcg} / \mathrm{kg} / \mathrm{min}\end{array}$ \\
\hline \multicolumn{6}{|c|}{ Central nervous system } \\
\hline GCS score & 15 & $13-14$ & $10-12$ & $6-9$ & $<6$ \\
\hline \multicolumn{6}{|l|}{ Renal } \\
\hline $\mathrm{SCr}, \mathrm{mg} / \mathrm{dL}$ & $<1.2$ & $1.2-1.9$ & $2.0-3.4$ & $3.5-4.9$ & $>5.0$ \\
\hline $\begin{array}{l}\text { Urinary output, } \\
\mathrm{mL} / \text { day }\end{array}$ & & & & $<500$ & $<200$ \\
\hline
\end{tabular}

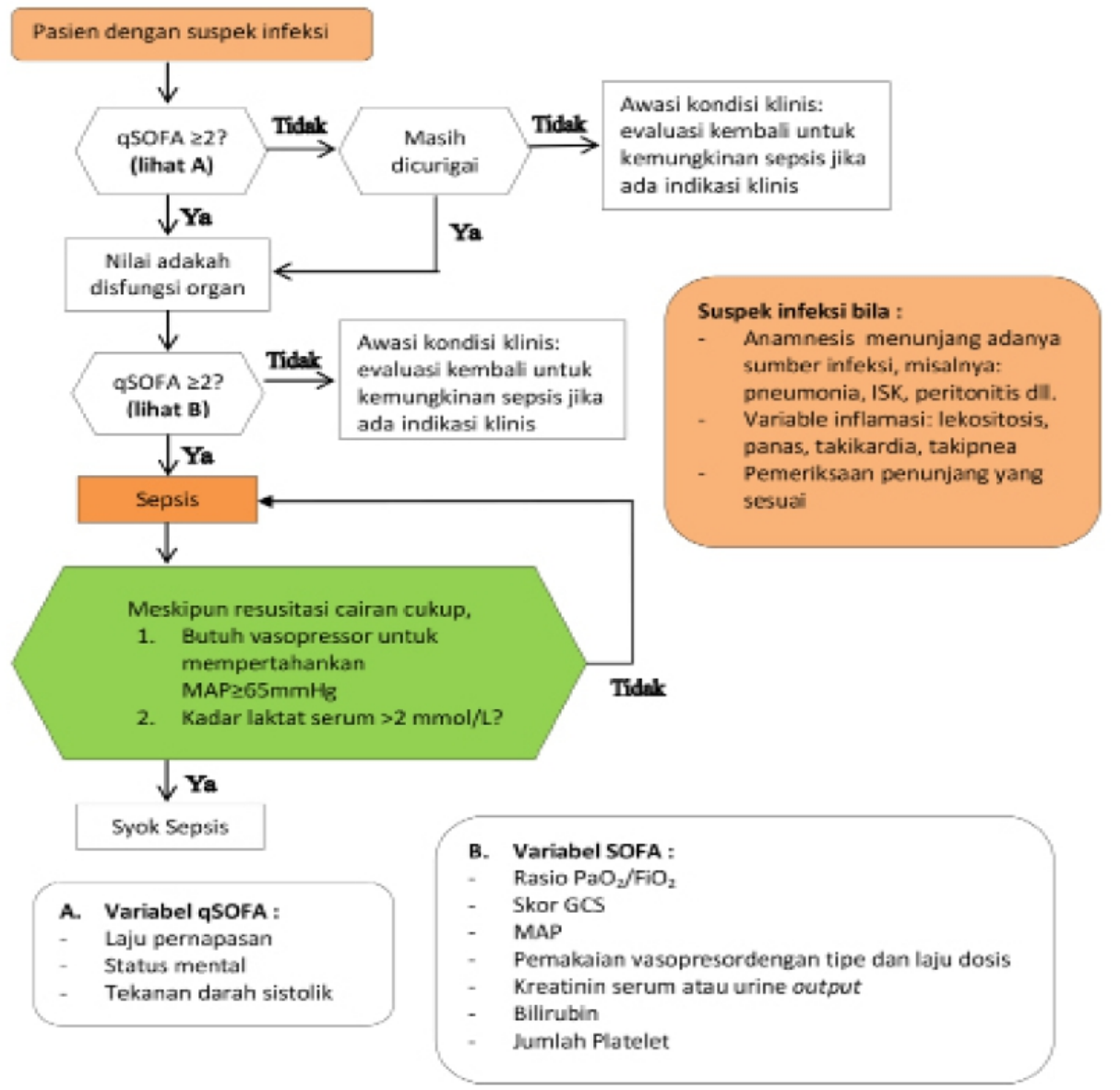

Gambar 2. Alur penapisan pasien dengan kecurigaan sepsis dan syok septik 
Kriteria simpel menggunakan qSOFA. qSOFA dinyatakan positif apabila terdapat 2 dari 3 kriteria. Skoring tersebut cepat dan sederhana serta tidak memerlukan pemeriksaan laboratorium (tabel 3$)^{7}$

Tabel 3. Skor quick SOFA (qSOFA)

\begin{tabular}{l}
\hline Kriteria qSOFA \\
\hline Laju pernapasan $>22 \mathrm{x} /$ menit \\
Perubahan status mental $/$ kesadaran \\
Tekanan darah sistolik $<100 \mathrm{mmHg}$ \\
\hline
\end{tabular}

Syok sepsis dapat diidentifikasi dengan adanya klinis sepsis dengan hipotensi menetap. Kondisi hipotensi membutuhkan pemberian tambahan vasopresor untuk mempertahankan MAP $>65 \mathrm{mmHg}$ dan laktat serum $>2 \mathrm{mmol} / \mathrm{L}$ walaupun telah dilakukan resusitasi (Gambar 2). ${ }^{7}$

\section{Penatalaksanaan Sepsis}

Waktu menjadi hal yang esensial dalam perkembangan tata laksana sepsis. Perubahan bermakna dalam surviving sepsis campaign 2018 dari rangkaian 3 jam, 6 jam, menjadi rangkaian 1 jam awal (hour-1 bundles). Perubahan ini diharapkan memberi perubahan pada manajemen resusitasi awal, terutama penanganan hipotensi pada syok septik. ${ }^{7}$

Resusitasi dini dan efektif merupakan kunci kesuksesan pasien syok sepsis. Komponen penting yang harus ditekankan pada saat resuitasi awal adalah terapi cairan yang tepat dan terapi vasopresor untuk mencapai target MAP $65 \mathrm{mmHg}$ sesegera mungkin. ${ }^{7}$

Pada tatalaksana sepsis terdahulu terdapat kekhawatiran penggunaan vasopresor pada resusitasi sepsis akibaat dari adanya potensi risiko vasokonstriksi prekapiler mikrovaskuler yang berlebihan. Namun demikian, hal ini disangkal oleh sejumlah uji klinis yang lebih baru yang menunjukkan efek positif pemberian vasopresor lebih awal. "Dini" dalam hal ini adalah masih tetap setelah pemberian terapi cairan dirasa tidak berhasil. Panduan semula merekomendasikan pemberian resusitasi dengan cairan kristaloid
IV diikuti dengan pemberian vasopresor jika pemberian kristaloid IV gagal mencapai target MAP $65 \mathrm{mmHg}$. Penelitian oleh Elbouhy et al menyatakan bahwa pemberian vasopresor sejak awal mampu mencapai target MAP $65 \mathrm{mmHg}$ lebih awal, klirens laktat lebih awal dan tercapainya ambang laktat $<2 \mathrm{mmol} / \mathrm{L}$ lebih awal, yang pada akhirnya meningkatkan keberhasilan terapi (survival). ${ }^{8}$

Dua hal penting yang harus digaris bawahi adalah, yang pertama, pemberian vasopresor sejak awal berkaitan dengan kebutuhan cairan resusitasi yang lebih sedikit, akumulasi cairan yang lebih sedikit, dan kemungkinan juga akan memperpendek waktu terjadinya hipotensi. Yang kedua, pemberian vasopresor sejak awal tidak mengakibatkan peningkatan resiko gangguan perfusi ginjal atau gangguan terkait iskemia lainnya; justru hal ini mungkin akan dapat menurunkan angka mortalitas pada pasien syok sepsis. ${ }^{8}$

Resusitasi pada kasus syok sepsis semula berdasarkan pada terapi cairan sebagai terapi lini pertama, yang akan diikuti dengan pemberian vasopresor saat pasien dianggap tidak respon terhadap terapi cairan. Walaupun hal ini masih diterima secara luas, namun praktek ini tidak didukung dengan bukti yang adekuat. Data penelitian pada kondisi "pre-vasopresor" pada kondisi syok sepsis masih sangat terbatas karena sebagian besar bukti resusitasi dini berorientasi pada hasil yang dianut saat ini merupakan penelitian randomized controlled trial, yaitu pasien sebelumnya telah mendapat sejumlah cairan yang telah ditentukan sebelumnya sebagai syarat inklusi dalam penelitian. Sebuah studi retrospektif terhadap fase "pre-vasopressor" yang memerlukan terapi vasopresor setidaknya selama 6 jam dan melakukan analisa dibanding sejumlah kecil kasus yang menggunakan terapi vasopresor kurang dari 6 jam. Pemberian vasopresor $<1$ jam sejak pemberian terapi cairan pertama kali (pemberian vasopresor sangat dini) mengakibatkan jumlah terapi cairan yang secara signifikan lebih rendah baik pada periode pre-vasopresor dan periode resusitasi awal. Total akumulasi cairan pada 8 dan 24 jam secara signifikan lebih rendah dan mortalitas secara signifikan juga lebih rendah. ${ }^{9}$

Studi observasional dan analisis post hoc pada sejumlah uji klinis terdahulu menemukan bahwa akumulasi cairan yang lebih besar berkaitan dengan luaran klinis lebih buruk. Efek pemberian 
vasopresor sangat awal terhadap jumlah akumulasi cairan yang lebih rendah tampaknya lebih cenderung diakibatkan oleh pembatasan pemberian cairan, dibanding meningkatkan laju eliminasi cairan. Penurunan angka mortalitas pada pasien dengan inisiasi dini vasopresor mungkin memiliki sejumlah penjelasan potensial, salah satunya adalah tercapainya restorasi aliran darah secara lebih cepat, disertai dengan akumulasi cairan yang lebih rendah, dapat memperbaiki perfusi jaringan dan mencegah terjadinya dampak negatif dari overload cairan. Yang menarik adalah pasien dengan pemberian vaspresor sangat awal memiliki tekanan darah pada saat bolus cairan pertama kali yang relatif sama dengan kelompok pasien dengan pemberian vasopresor lambat, menunjukkan bahwa perbedaan tersebut lebih berkaitan dengan kapan saatnya inisiasi vasopresor daripada derajat hipotensi. ${ }^{9}$

Pemberian terapi vasopresor sejak dini dapat merubah perjalanan hemodinamik pada syok septik. Penelitian eksperimental berkenaan dengan endotoksemia menunjukkan bahwa resusitasi cairan dapat meningkatkan kebutuhan vasopresor dibanding jika vasopresor diberikan sejak awal. Sejalan dengan itu, penelitian oleh Ospina-Tascon et al melaporkan penggunaan vasopresor dengan dosis yang lebih rendah jika terapi vasopresor diberikan sejak awal, setidaknya dalam 6 jam pertama resusitasi. Artinya, onset awal terapi vasopresor akan dapat mencegah progresi dari gangguan sirkulasi. Ada kekhawatiran yang berkembang mengenai dampak vasopresor terhadap perfusi splanknik jika pada pasien tersebut juga dijumpai hipovolemia. Untuk menjawab hal tersebut, sejumlah penelitian eksperimental melaporkan mengenai kombinasi pemberian vasopresor dan terapi cairan sejak awal terhadap aliran darah splanknik. Intervensi berupa pemberian vasopresor dini tidak mengakibatkan gagal ginjal akut ataupun mengakibatkan peningkatan kebutuhan terapi penggantian fungsi ginjal. Penelitian Ospina-Tascon et al menyimpulkan bahwa kombinasi dari memendeknya jangka waktu hipotensi, penurunan jumlah kebutuhan cairan prevasopresor dan post-vasopresor, yang tentunya menurunkan jumlah akumulasi cairan, kemungkinan besar berdampak pada luaran klinis. Penelitian ini tidak serta mendukung penggunaan "hour-1 bundle" seperti yang barubaru ini dikampanyekan, namun menyoroti pada hipotesis mengenai manfaat pemberian dini vasopresor pada pasien dengan syok sepsis, dengan penekanan bahwa kelompok perlakuan mendapat terapi vasopresor dini tanpa menyelesaikan terapi cairan dengan jumlah yang telah ditentukan sebelumnya. Sehingga, dapat disimpulkan bahwa pemberian vasopresor sejak awal akan menurunkan jumlah cairan resusitasi yang diperlukan, jumlah akumulasi cairan yang lebih rendah, dan jangka waktu hipotensi yang lebih pendek. Pemberian vasopresor sebelum terapi resusitasi cairan selesai diberikan dipandang sebagai suatu intervensi yang cukup aman dan memiliki potensi memperbaiki luaran klinis. ${ }^{10}$

Perubahan yang paling penting dalam revisi surviving sepsis campaign bundles adalah bahwa paket 3 jam dan 6 jam dilebur menjadi satu, disebut sebagai "hour 1 bundles", yang secara eksplisit bertujuan memulai resusitasi dan tata laksana sesegera mungkin. Hal ini merefleksikan kenyataan klinis, bahwa dalam penanganan pasien dengan sepsis dan syok sepsis maka dokter akan memulai pemberian terapi sesegera mungkin, terutama pada pasien dengan hipotensi. Kemungkinan diperlukan waktu lebih dari 1 jam untuk menyelesaikan resusitasi, namun inisiasi resusitasi dan tata laksana, seperti misalnya pengambilan sampel darah untuk pengukuran laktat dan kultur darah, pemberian cairan dan antibiotik, dan inisiasi pemberian vasopresor pada kasus hipotensi berat, semua dilakukan secara bersamaan. ${ }^{11}$

Perlu lebih banyak penelitian mengenai efikasi hour-1 bundles pada subgroup tertentu, di antaranya pasien luka bakar dan pasien dengan gangguan sistem imun. Revisi paket manajemen sepsis ini merupakan gambaran akurat dari perawatan klinis aktual di lapangan. Elemenelemen yang masuk dalam revisi panduan Surviving Sepsis Campaign dan level of evidence masing-masing komponen disarikan dalam Tabel 4. ${ }^{12}$

\section{Pengukuran Kadar Laktat}

Meskipun kadar laktat dalam serum bukan merupakan pengukuran langsung terhadap perfusi jaringan, namun bisa digunakan sebagai indikator. Kenaikan laktat dapat menggambarkan hipoksia 
Tabel 4. Komponen tata laksana dan level of evidence

\begin{tabular}{ll}
\hline Bundle element & Grade of recommendation and level of evidence \\
\hline Measure lactate level. Re-measure if initial lactate is $>2 \mathrm{mmol} / \mathrm{L}$ & Weak recommendation, low quality of evidence \\
Obtain blood cultures prior to administration of antibiotics & Best practice statement \\
Administer broad-spectrum antibiotics & Strong recommendation, moderate quality of evidence \\
Rapidly administer $30 \mathrm{ml} / \mathrm{kg}$ crystalloid for hypotension or lactate $\geq 4 \mathrm{mmol} / \mathrm{L}$ & Strong recommendation, low quality of evidence \\
$\begin{array}{l}\text { Apply vasopressors if patient is hypotensive during or after fluid resuscitation to maintain } \\
\text { MAP } \geq 65 \mathrm{~mm} \mathrm{Hg}\end{array}$ & Strong recommendation, moderate quality of evidence \\
\hline
\end{tabular}

jaringan, peningkatan glikolisis aerobik yang disebabkan peningkatan stimulasi beta adrenergik, atau penyebab lain yang berkaitan dengan luaran yang lebih buruk. Sejumlah penelitian randomized controlled trial menunjukkan hasil penurunan angka mortalitas pada resusitasi dengan panduan laktat. Jika kadar laktat awal mengalami peningkatan $(>2$ $\mathrm{mmol} / \mathrm{L}$ ), sebaiknya dilakukan pengukuran ulang dalam 2-4 jam sebagai panduan resusitasi untuk menormalkan laktat pada pasien yang mengalami peningkatan kadar laktat sebagai penanda hipoperfusi jaringan. ${ }^{13}$

\section{Pemeriksaan Kultur Darah}

Penggunaan antibiotika yang tepat dapat memperbaiki kultur darah sejak pemberian dosis pertama. Dengan demikian penting artinya untuk melakukan pemeriksaan kultur darah sebelum pemberian terapi antibiotika, untuk mengidentifikasi pathogen dengan lebih akurat dan memperbaiki luaran klinis. Pemeriksaan kultur darah sebaiknya dilakukan 2 seri, pemeriksaan kultur aerobik dan anaerobik. Namun, pemberian terapi antibiotika yang sesuai hendaknya tidak ditunda untuk mendapatkan hasil kultur darah. ${ }^{14}$

\section{Pemberian Antibiotika Spektrum Luas}

Terapi antibiotika spektrum luas dengan 1 jenis atau lebih antimikroba intravena untuk menjangkau semua patogen potensial harus dimulai sesegera mungkin pada pasien dengan sepsis dan syok sepsis. Terapi antibiotika empiris hendaknya dapat dipersempit begitu patogen dan sensitivitas terkait dapat diidentifikasi, atau dihentikan jika pasien telah bebas infeksi. Hubungan antara terapi antibiotika dini untuk infeksi yang dicurigai dan peran antibiotik masih menjadi aspek penting dalam tata laksana sepsis yang berkualitas. Jika pada akhirnya tidak terbukti adanya infeksi, maka terapi antibitika hendaknya dihentikan. ${ }^{15}$

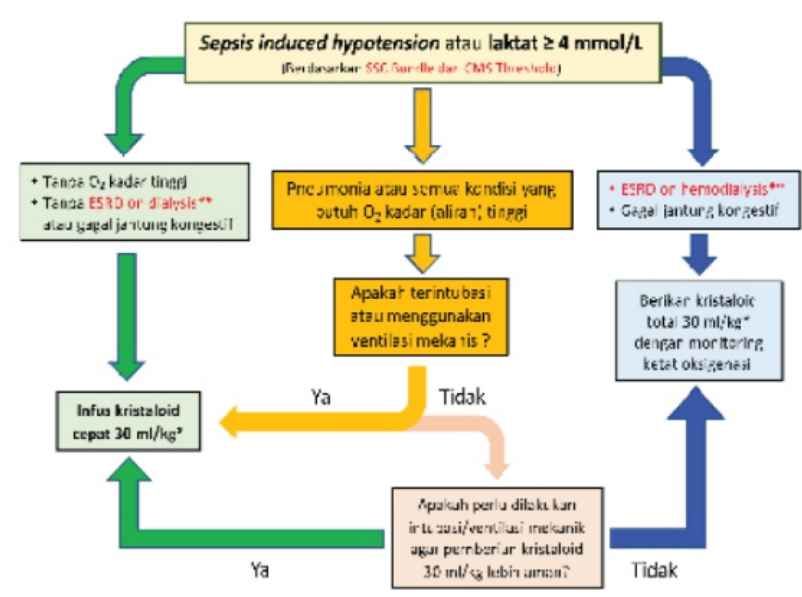

Gambar 3. Panduan tata laksana resusitasi cairan pada syok septik

\section{Pemberian Cairan Intravena}

Resusitasi cairan secara efektif sangat penting untuk stabilisasi hipoperfusi jaringan yang diinduksi oleh sepsis atau syok sepsis. Mengingat sepsis atau syok sepsis merupakan kegawatdaruratan medis, pemberian resusitasi cairan harus dikerjakan segera setelah teridentifikasi bahwa pasien mengalami sepsis dan/atau hipotensi dan peningkatan kadar laktat, selesai dalam jangka waktu 3 jam. Panduan penanganan sepsis merekomendasikan pemberian minimum $30 \mathrm{~mL} / \mathrm{kg}$ cairan kristaloid intravena. Walaupun hanya sedikit literatur yang memiliki data untuk mendukung dosis volume tersebut, sejumlah penelitian intervensional mendeskripsikan dosis volume tersebut di atas sebagai jumlah yang lazim diberikan pada tahap awal resusitasi dan didukung oleh data 
observasional. Tidak dijumpai adanya manfaat jelas pada pemberian cairan koloid dibandingkan kristaloid pada kelompok pasien dengan sepsis, mendukung rekomendasi kuat penggunaan cairan kristaloid pada tahap awal resusitasi pasien dengan sepsis dan syok sepsis. Pemberian cairan setelah resusitasi awal harus diperhitungkan secara cermat mengingat sejumlah bukti mengindikasikan bahwa mempertahankan pemberian balans cairan positif pada pasien ICU bisa jadi berbahaya. ${ }^{16}$

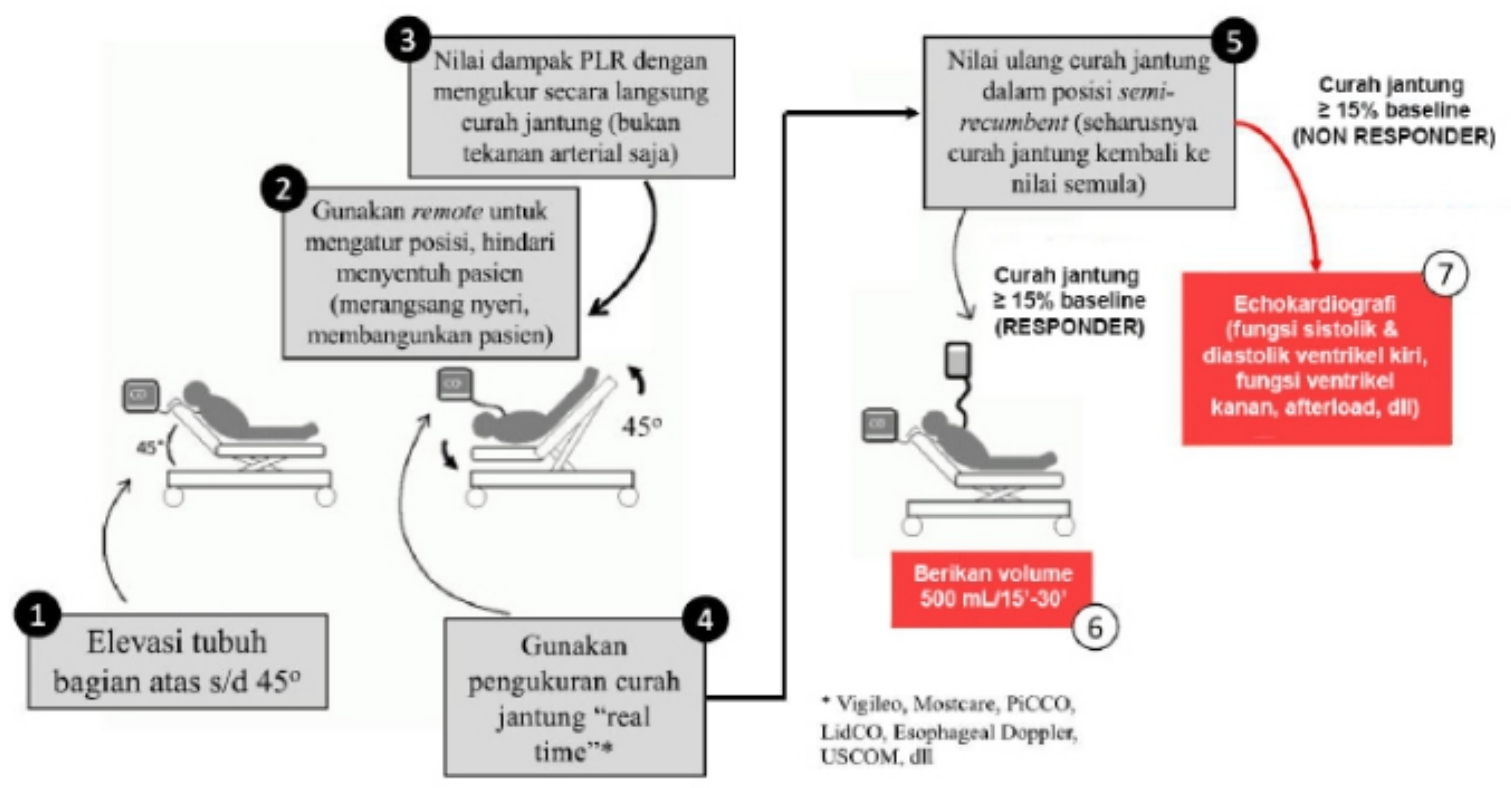

Gambar 4. Prosedur passive leg raising test untuk menilai responsivitas terhadap cairan atau pulse pressure. Jika alat pengukur curah

\section{Penilaian Respon Cairan}

Passive leg raising test

Penilaian dapat digunakan pada pasien yang bernapas spontan ataupun dengan ventilator, serta merupakan tes yang cukup akurat untuk pasien dengan aritmia. Peningkatan curah jantung lebih dari $10 \%$ atau $15 \%$ dari nilai awal merupakan tolok ukur yang cukup akurat untuk menentukan pasien tergolong responsif atau tidak. Jika tidak tersedia monitoring curah jantung, maka sebagai alternatif dapat dihitung besarnya pulse pressure (perbedaan antara tekanan sistolik dan diastolik). Jika pulse pressure bertambah $>10 \%$ dari nilai dasar, maka pasien dianggap responsif, namun metode ini memiliki sensitivitas dan spesifisitas lebih rendah dibanding metode pemeriksaan curah jantung. ${ }^{17}$

\section{Fluid challenge test}

Metode ini mengukur perubahan stroke volume jantung, atau tekanan sistolik arterial, jantung atau echokardiografi tidak tersedia, dapat dikerjakan pengukuran perubahan CVP, walau akurasinya tidak sebaik echokardiografi dan pengukuran CVP. ${ }^{18}$

\section{Stroke volume variation (SVV)}

Metode ini merupakan variasi pemeriksaan stroke volume jantung akibat perubahan tekanan intra torakal saat pasien menggunakan ventilasi mekanik. Syarat penilaian responsivitas cairan dengan metode ini adalah:

\section{Pasien dalam kontrol ventilasi mekanis penuh}

2.Volume tidal $8-10 \mathrm{~mL} / \mathrm{kgBB}$ (predicted body weight)

3.Tidak ada aritmia. Pasien masuk kategori responsif bila $\mathrm{SVV} \geq 12 \%$

Selain SVV, pulse pressure variation (PPV) juga dapat dipergunakan untuk menilai responsivitas cairan. ${ }^{19}$ 


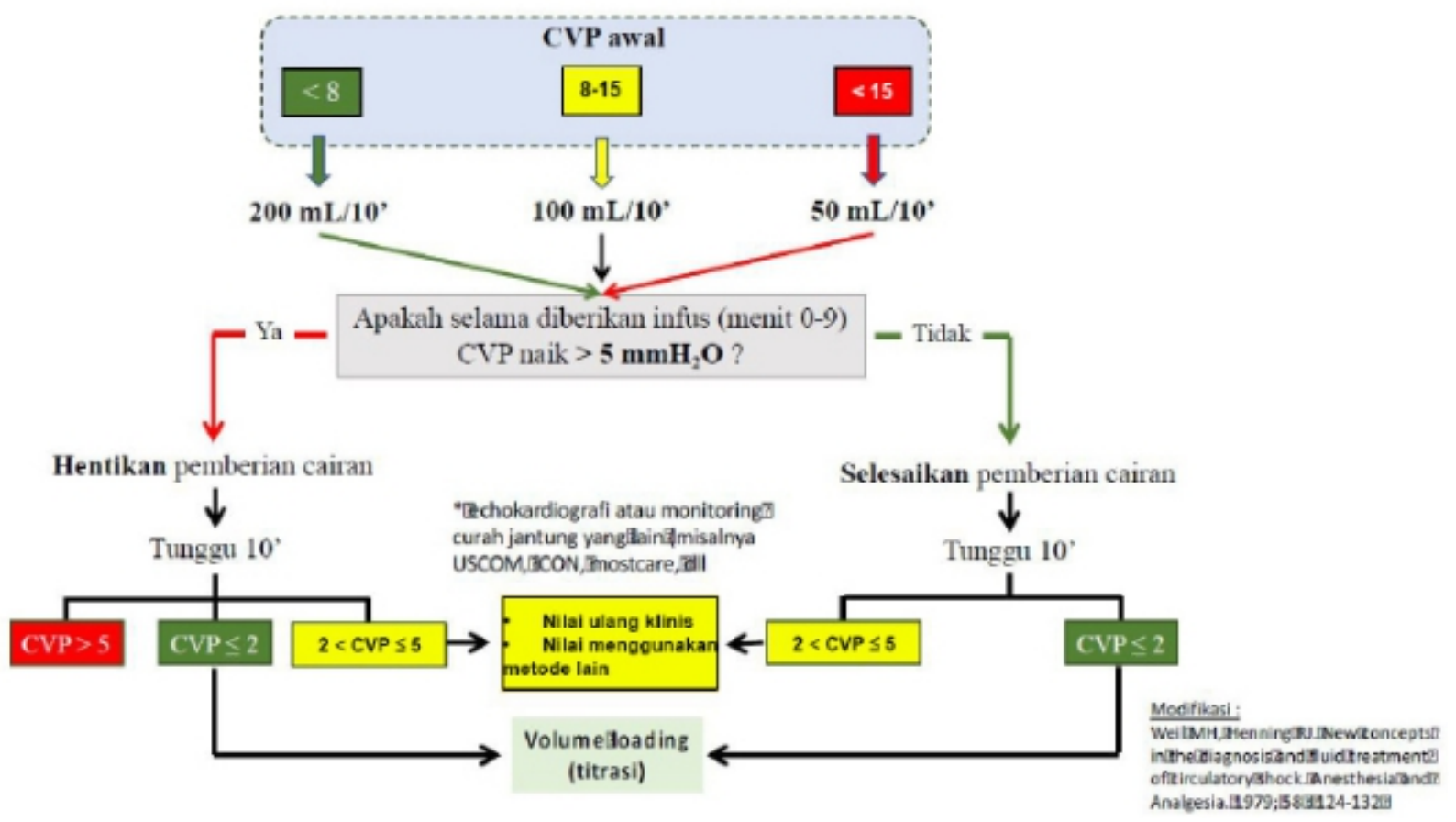

Gambar 5. Algoritma penilaian CVP sebagai panduan resusitasi cairan pasien kritis

\section{Indikator Keberhasilan Resusitasi Awal}

Mean arterial pressure (MAP)

MAP merupakan tekanan yang menentukan perfusi ke jaringan atau organ. Rekomendasi target MAP pada pasien syok septik yang membutuhkan vasopresor adalah $65 \mathrm{mmHg}$. Target MAP tersebut merupakan parameter makrosirkulasi yang pada umumnya harus dicapai sesegera mungkin. Hipotensi arterial yang berkepanjangan dapat memberat outcome klinis dan meningkatkan mortalitas. Upaya resusitasi awal dengan pemberian cairan yang adekuat dan penggunaan vasopressor lebih dini pada kasus hipotensi yang mengancam nyawa diharapkan akan meningkatkan survival. ${ }^{20}$

Laktat

Monitoring keberhasilan resusitasi diperoleh dari data status klinis pasien. Prinsip terpenting dalam penanganan pasien yang kompleks adalah perlunya pengambilan data dasar yang akurat dan selanjutnya dikerjakan re-evaluasi secara berkala untuk mengevaluasi respon pasien terhadap terapi yang diberikan.

Peningkatan kadar laktat dalam plasma, apapun kausanya, memiliki korelasi dengan outcome klinis yang lebih buruk. Karena laktat merupakan pemerikaan standard laboratorium dengan metode ppengukuran yang sudah baku, maka penggunaan kadar laktat sebagai indikator perfusi jaringan dianggap lebih objektif dibanding pemeriksaan fisik dan produksi urine. Keberhasilan resusitasi pada pasien sepsis dapat dinilai dengan memantau penurunan kadar laktat. ${ }^{20}$

Central venous pressure (CVP) dan saturasi vena sentral (ScVO2)

Penggunaan CVP sebagai parameter tunggal untuk memantau resusitasi tidak lagi direkomendasikan. Saat CVP dalam kisaran normal (8-12 $\mathrm{mmHg}$ ) kemampuan CVP untuk menilai responsivitas cairan terbukti tidak akurat. Hal ini berlaku juga untuk pemeriksaan statis lain yang mengukur perubahan tekanan atau volume jantung kanan atau kiri, misalnya tekanan oklusi arteri pulmonalis. Penggunaan target CVP secara absolut cenderung mengakibatkan resusitasi cairan yang berlebihan. ${ }^{20}$

Perbedaan $\mathrm{CO} 2$ arteri dan vena $(\mathrm{Pv}-\mathrm{a} \mathrm{CO} 2)$

Perbadaan $\mathrm{CO} 2$ diteliti sebagai penanda hipoperfusi jaringan. Peningkatan produksi $\mathrm{CO} 2$ merupakan salah satu gambaran dari adanya metabolisme anaerob. Penilaian terhadap indikator ini dapat dikorelasikan dengan peningkatan kadar 
laktat, akan membantu evaluasi pada pasien kritis lebih akurat. Bila terjadi peningkatan kadar laktat yang disertai dengan peningkatan $\mathrm{Pv}-\mathrm{a} \mathrm{CO} 2$, maka kemungkinan besar penyebabnya adalah hipoperfusi. ${ }^{20}$

\section{Pemberian Vasopresor}

Dua komponen utama resusitasi pada pasien syok sepsis adalah pemberian cairan intravena dan vasopresor. Penelitian terbaru pasien syok septik merekomendasikan bahwa vasopresor (norepinefrin sebagai pilihan pertama) diberikan untuk mempertahankan perfusi pada organ vital dan mengurangi durasi waktu kejadian hipotensi. Mengembalikan tekanan perfusi ke organ vital secepat mungkin merupakan bagian penting resusitasi dan tidak boleh ditunda. Untuk resusitasi awal dengan target tujuan rata-rata tekanan arteri (MAP) > $65 \mathrm{mmHg}$. Pada kasus syok sepsis hipotensi yang terjadi tidak hanya disebabkan oleh karena hipovolemia relatif atau absolut, tetapi juga karena terjadinya vasoplegia yang membutuhkan pemberian vasopresor segera. Norepinefrin (NEP) direkomendasikan sebagai vasopresor lini pertama, dapat dilakukan penambahan vasopressin (hingga $0.03 \mathrm{U} /$ menit). Penambahan pemberian vasopressin lebih dini dapat dipertimbangkan untuk mengurangi dosis NEP. ${ }^{21}$

Norepinephrine merupakan agonis reseptor adrenergik yang bekerja meningkatkan resistensi dan perifer dan tekanan darah melalui efek vasokonstriksi perifer. Noerepinephrine terdistribusi lokal terutama pada jaringan saraf simpagtis fdan menembus sawar plasenta namun tidak menembus sawar darah otak. NEP memiliki onset dan durasi yang cepat, bahkan berakhir 1-2 menit setelah pemberian lewat infus distop. Apabila target MAP $65 \mathrm{mmHg}$ telah tercapai atau perfusi jaringan telah adekuat pemberian NEP harus dikurangi secara bertahap atau titrasi untuk mencegah penurunan tekanan darah yang mendadak. ${ }^{21}$

Penggunaan dobutamin sebagai vasopresor alternatif hanya direkomendasikan pada pasen dengan resiko rendah untuk terjadinya takiaritmia dan mengalami bradikardi absolut atau relative. Pemberian dobutamin dosis rendah yang bertujuan sebagai proteksi ginjal tidak lagi direkomendasikan. Rekomendasi pemberian dobutamine hanya pada pasen hipotensi menetap walaupun telah diberikan cairan yang adekuat dan vasopresor. ${ }^{22}$

Pemberian cairan intra vena diawal untuk support hemodinamik sangat dibolehkan, tetapi pemberian dalam volume yang lebih besar dari cairan resusitasi dapat meningkatkan edema ekstravaskular, memperburuk disfungsi paru dan oksigenasi jaringan. Hal ini juga dapat mengakibatkan episode hipotensi yg lebih lama dan golden periode penyelamatan pasen akan berkurang sampai hilang. Hal ini yg menyebabkan studi yang membahas penggunaan awal NEP di sepsis prospektif sangat terbatas. ${ }^{23}$

Pemberian NEP di awal dikaitkan dengan durasi hipotensi yg lebih singkat. Dalam studi prospektif acak yg dilakukan Permpikul et al juga menunjukkan bahwa penggunaan awal NEP menyebabkan target MAP $65 \mathrm{mmHg}$ dapat tercapai lebih cepat. Penggunaan dini NEP dapat meningkatkan tekanan perfusi, meningkatkan stroke volume dan cardiac output. Penggunaan NEP untuk mengembalikan MAP untuk meningkatkan kontraksi otot pembuluh darah sehingga oksigenasi jaringan akan meningkat pada pasien syok septik. Hal ini berbanding lurus antara peningkatan MAP, perfusi organ, dan peningkatan clearance laktat serum. Penelitian ini menemukan penurunan $37,8 \%$ pada level serum laktat setelah resusitasi dengan penggunaan awal NEP dibandingkan dengan $22,2 \%$ saat NEP digunakan setelah resusitasi. Sekitar setengah dari pasien dalam kelompok awal mencapai tingkat laktat serum di bawah $2 \mathrm{mmol} / \mathrm{L} 6$ jam setelah masuk dibandingkan dengan hanya $27,3 \%$ dari kelompok control yg pemberian NEP lambat. Studi lain juga menunjukkan bahwa konsentrasi laktat yang diukur 3 jam setelah syok sepsis endotoksik pada hewan model lebih rendah dengan penggunaan awal NEP dibandingkan dengan kelompok lain dari cairan iv dan penggunaan akhir NEP. Kadar serum laktat lebih rendah pada pemberian di awal NEP dikonfirmasi secara dini dalam studi observasi retrospektif yang menunjukkan tingkat laktat lebih rendah pada setiap poin setelah resusitasi mulai dari 2 hingga 8 jam. $^{24}$

Penurunan angka mortalitas atau keberhasilan dalam penanganan pasien syok sepsis yang diberikan NEP di awal berhubungan dengan 
kecepatan tercapainya nilai MAP dan clearance laktat. Pada beberapa penelitian lain juga dijelaskan semakin cepat waktu pencapaian MAP besar sama dengan 65 $\mathrm{mmHg}$ dan penurunan nilai laktat maka akan menurunkan mortalitas di ICU, sehingga dapat dijadikan prediktor angka mortalitas pasien syok sepsis yang dirawat di ICU. ${ }^{25,26}$

Salah satu temuan menarik dari studi pemberian NEP dini didapatkan volume cairan intravena yang lebih rendah untuk resusitasi dibandingkan kelompok kontrol. Penggunaan NEP dini dapat meningkatkan tekanan arteri dan aliran balik vena. Hal itu dibuktikan dengan penurunan variasi tekanan nadi yang merupakan indikator respon volume cairan. Penggunaan dini NEP berkontribusi terhadap penurunan volume intravaskular dan disebut dengan vasoconstritor masked hypovolemia. ${ }^{26-29}$

\section{KESIMPULAN}

Pada pasien syok septik penggunaan NEP meningkatkan aliran darah splanknik, pengantaran oksigen dan pengambilan oksigen. Pada beberapa penelitian dijelaskan pemberian infus norepinephrine menunjukkan peningkatan aliran darah ginjal dan koroner. Penggunaan dini NEP bersamaan dengan cairan intravena dalam penanganan resusitasi pasien syok sepsis dapat meningkatkan tekanan arteri, clearance laktat dan menurunkan kebutuhan cairan resusitasi yang dengan sendirinya akan meningkatkan harapan hidup pasien syok sepsis serta menurunkan mortalitas di ICU.

\section{DAFTAR PUSTAKA}

1. Yang RL. Taryn BB. CCSAP BOOK 1 septic management . 2019.7-31.

2. Rhodes A, Evans LE, Alhazzani W, et al. Surviving Sepsis Campaign: International Guidelines for Management of Sepsis and Septic Shock: 2016. Intensive Care Med 2017.

3. Kadri SS, Rhee C, Strich JR, et al. Estimating ten-year trends in septic shock incidence and mortality in United States academic medical centers using clinical data.
Chest 2017;151:278-85.

4. Rhee C, Dantes R, Epstein L, et al. Incidence and trends of sepsis in US hospitals using clinical vs. claims data, 2009-2014. JAMA 2017;218:1241-9.

5. Menteri Kesehatan Republik Indonesia. Pedoman Nasional Pelayanan Kedokteran Tata Laksana Sepsis. Nomor Hk.01.07/Menkes/342/2017. 2017

6. Minasyam H. Septic and septic shock: pathogenesis and treatment perspective: researchgate. Journal of Critical Care 2017;40:229-42.

7. Pangalila FJU, Mansjoer A. Penatalaksanaan sepsis dan shock septik. Jakarta; PERDICI, 2017.

8. Meier-Hellmann A, Specht M, Hannemann L et al. Splanchnic flow is greater in septic shock treated with norepinephrine than in severe sepsis. Int Care Med. 1996; 22 :1354-9.

9. Di Giantomasso D, May CN, Bellomo R. Norepinephrine and vital organ blood flow.Int Care Med 2002; 28: 1804-9.

10. Martin C, Viviand X, Arnaud S et al. Effects of norepinephrine plus dobutamineor norepinephrine alone on left ventricular performance of septic shock patients. Crit Care Med 1999; $7:$ 1708-13.

11. Day NP, Phu NH, Bethell DP et al. The effects of dopamine and adrenaline infusions on acidbase balance and systemic haemodynamics in severe infections. Lancet 1996; 348 : 219-223.

12. De Backer D, Aldecoa C, Njimi H, VincentJL. Dopamine versus norepinephrine in the treatment of septic shock: a meta-analysis. Crit Care Med 2012; 40 : 725-30.

13. Vasu TS, Cavallazzi R, Hirani A et al.Norepinephrine or dopamine for septic shock: a systematic review of randomized controlled trials. J Intensive Care Med 2012; 27 : 172-8.

14. Dellinger RP, Levy MM, Rhodes A et al. Surviving Sepsis Campaign: International guidelines for management of severe sepsis and septic shock: 2012. Crit Care Med 2013; 41 : 580-637.

15. Devins SS, Miller A, Herndon BL et al. Effects of dopamine on T-lymphocyte proliferative responses and serum prolacti concentrations in 
critically ill patients. Crit Care Med 1992; $20: 1644-9$.

16. Neviere R, Mathieu D, Chagnon JL et al. The contrasting effects of dobutamine and dopamine on gastric mucosal perfusion in septic patients. Am J Resp and Crit Care Med 1996; $154: 1684-8$

17. Rhodes A, Evans LE, Alhazzani W, et al. Surviving Sepsis Campaign: International Guidelines for Management of Sepsis and Septic Shock: 2016. Intensive Care Med 2017;43:304e377.

18. Levy MM, Evans LE, Rhodes A. The Surviving Sepsis Campaign Bundle: 2018 update. Intensive Care Med 2018;44:925e928.

19. Permpikul C, Tongyoo S, Viarasilpa T, et al. Early Use of Norepinephrine in Septic Shock Resuscitation (CENSER) : A Randomized Trial. Am J Respir Crit Care Med 2019;199:1097e1105.

20. Bai X, Yu W, Ji W, et al. Early versus delayed administration of norepinephrine in patients with septic shock. Crit Care 2014;18:532.

21. Hamzaoui O, Georger J-F, Monnet X, et al. Early administration of norepinephrine increases cardiac preload and cardiac output in septic patients with life-threatening hypotension. Crit Care 2010; 14:R142.

22. Georger J-F, Hamzaoui O, Chaari A, et al. Restoring arterial pressure with norepinephrine improves muscle tissue oxygenation assessed by near-infrared spectroscopy in severely hypotensive septic patients. Intensive Care Med 2010;36:1882e1889.
23. Sennoun N, Montemont C, Gibot S, et al. Comparative effects of early versus delayed use of norepinephrine in resuscitated endotoxic shock. Crit Care Med 2007;35:1736e1740.

24. Lankadeva YR, Kosaka J, Evans RG, et al. Intrarenal and urinary oxygenation during norepinephrine resuscitation in ovine septic acute kidney injury. Kidney Int 2016;90:100e108.

25. Subramanian S, Yilmaz M, Rehman A, et al. Liberal vs. Conservative vasopressor use to maintain mean arterial blood pressure during resuscitation of septic shock: an observational study. Intensive Care Med 2008;34:157e162.

26. Persichini R, Silva S, Teboul J-L, et al. Effects of norepinephrine on mean systemic pressure and venous return in human septic shock. Crit Care Med 2012;40:3146e3153.

27. Hinder F, Stubbe HD, Van Aken H, et al. Early multiple organ failure after recurrent endotoxemia in the presence of vasoconstrictormasked hypovolemia. Crit Care Med 2003;31:903e909.

28. Mamta Patel,Fang Gao Smith . Vasoactive Drugs. Cambridge University Press 2019

29. Shields, SH Holland. Pharmacology of Vasopressors and Inotropes, Tintinalli's emergency medicine a comprehensive study guide, 8 edn, mcgraw-hill education, United States, pp.143-146 